\title{
THE COAGULATION PROPERTIES OF HUMAN ERYTHROCYTES
}

\author{
BY \\ U. M. SERAFINI AND G. CENTURELLI \\ From the Postgraduate Medical School of Haematology, University of Rome
}

(RECEIVED FOR PUBLICATION JANUARY 1, 1958)

A thromboplastic factor has been demonstrated
in human red cells by Shinowara (1951) Ottaviani, Dettori, and Manai (1954), Quick, Georgatsos, and Hussey (1954), Leupold (1955), Bounameaux (1957a), and Georgatsos, Hussey, and Quick (1955), and named the "erythrocyte clotting factor" (E.C.F.). Its activity is similar though not identical with that of platelet factor 3 . Thromboplastic activity is not produced by whole erythrocytes, but only after lysis by freezing or dilution with distilled water. Lysed erythrocytes increase the prothrombin consumption of plateletpoor or platelet-rich plasma and restore to normal the prolonged recalcification time and the impaired prothrombin consumption of a thrombocytopenic plasma (Georgatsos et al., 1955). The E.C.F. activity depends on the presence of thromboplastinogen (Izarn, Hussey, and Quick, 1955). The increase of prothrombin consumption of a platelet-free haemophilic plasma, to which thromboplastinogen is added, is higher when platelets are replaced by lysed erythrocytes, when there is a linear relationship between this increase and the amount of thromboplastinogen.

The prothrombin consumption test in the presence of lysed erythrocytes, as suggested by Izarn et al. (1955), should therefore be very sensitive in detecting small quantities of thromboplastinogen or antihaemophilic globulin (A.H.G.) and it should be useful in differentiating between mild and severe A.H.G. deficiencies.

It was also shown by Leupold (1955), Georgatsos et al. (1955), and Bounameaux (1957a) that lysed red cells can be substituted for platelets in the thromboplastin generation test of Biggs and Douglas (1953).

This paper records an investigation into the coagulation properties of lysed erythrocytes. The possible interference of lysed erythrocytes in the various stages of the clotting process has been investigated and a study made as to whether other activities might be detected in red cells comparable with those already found in platelets by Deutsch,
Johnson, and Seegers (1955). A preliminary report on the antiheparin activity of lysed erythrocytes has been published (Serafini and Centurelli, 1957).

\section{Methods}

Preparation of Lysed Erythrocytes (Haemolysate). - Nine volumes of human blood, taken into siliconed glassware after a clean venepuncture from a healthy person, were mixed with one volume of $0.1 \mathrm{M}$ sodium oxalate and then centrifuged at 800 r.p.m. for five minutes. The platelet-containing plasma was pipetted off and the packed red cells were washed eight times with buffered saline, which, after slow centrifugation, was removed. After the last washing, red cells were centrifuged at 5,000 r.p.m. for $30 \mathrm{~min}$. and the supernatant saline was removed. A concentrated haemolysate, obtained by freezing at $-20^{\circ}$ C. for 12 hours, was obtained from a suspension of $8-10,000,000$ red cells per c.mm., containing only $500-2,000$ platelets or their fragments per c.mm. After thawing, the haemolysate was stored at $-20^{\circ} \mathrm{C}$. and warmed to $37^{\circ} \mathrm{C}$. before the experiments. Different dilutions of haemolysate in buffered saline (imidazole buffer at $p \mathrm{H}$ 7.3) were used.

Thromboplastic Activity.-This was assayed by the prothrombin consumption test of Merskey (1950) on $0.4 \mathrm{ml}$. of platelet-poor human oxalated plasma, to which $0.2 \mathrm{ml}$. of different concentrations of haemolysate or saline or of a platelet suspension and $0.2 \mathrm{ml}$. of $0.050 \mathrm{M} \mathrm{CaCl}_{2}$ were added.

The thromboplastic activity of the haemolysate was also assayed by the thrombin generation test of Pitney and Dacie (1953), modified by O'Brien (1955), and by the thromboplastin generation test of Biggs and Douglas (1953).

The prothrombin consumption test of blood from cases of haemophilia or Christmas disease to which haemolysate has been added before clotting was tested by the method of Quick and Favre-Gilly (1949).

Antiheparin Activity. - Platelet-poor plasma samples containing different quantities of heparin $(0.25$ to 1 I.U. per ml.) were mixed with equal volumes of haemolysate or with a platelet suspension of 300,000 per c.mm. or buffered saline as control. 
After incubation for $15 \mathrm{~min}$. at room temperature, a constant volume of a thrombin solution ("thrombin," Roche) in imidazole buffer at $p \mathrm{H} 7.3$ was added and the clotting time recorded. The present method does not depend on the erythrocyte thromboplastic activity and measures only the ability of the test material to neutralize the antithrombin activity of heparin.

Effect on Thrombin-fibrinogen Reaction.-Samples of a fibrinogen solution ("fibrinogen," Behring), containing $0.2 \mathrm{~g}$. per $100 \mathrm{ml}$. in buffered saline at

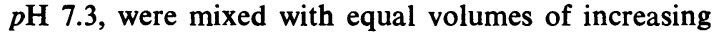
concentrations of haemolysate or of a platelet suspension of 300,000 per c.mm. or saline as control. A constant volume of a thrombin solution in imidazole buffer was added and the clotting times recorded.

Factor V and Factor VII Activity.-Factor V was assayed by the method of Quick and Stefanini (1948) using oxalated human plasma stored for 18 hours at $37^{\circ} \mathrm{C}$. as a substrate according to Wolf (1953), and factor VII by the method of Koller, Loeliger, and Duckert (1951). In both methods test plasma was replaced by haemolysate or controls.

Test for Factor VII Inhibition.-Factor VII activity of a normal serum was tested by the method of Koller et al. (1951) before and after incubation at $37^{\circ} \mathrm{C}$. for $30 \mathrm{~min}$. with increasing concentrations of haemolysate or controls.

Quick Times and Stypven Times.-The effect of different concentrations of haemolysate on the clotting time of a normal plasma, to which brain thromboplastin or Russell viper venom ("stypven," Burroughs Wellcome) diluted 1 in 3 in saline, and then $0.025 \mathrm{M} \mathrm{CaCl}_{2}$ added, was investigated.

Tests for Anti-brain Thromboplastin and Antiplasma Thromboplastin Activity.-The method of Tocantins (1943) for antithromboplastin activity was modified. Brain thromboplastin was incubated with haemolysate for $15 \mathrm{~min}$. at $37^{\circ} \mathrm{C}$. and then added to normal plasma, together with $0.025 \mathrm{M} \mathrm{CaCl}$. Alternatively brain thromboplastin was incubated with haemolysate and normal plasma for $15 \mathrm{~min}$. at $37^{\circ} \mathrm{C}$. and then the mixture was recalcified. Clotting times before and after incubation were compared.

An inhibiting effect on plasma thromboplastin was investigated adding undiluted haemolysate, or buffered saline as a control, to the mixture of a normal thromboplastin generation test soon after the shortest clotting time of the substrates was reached. The rate of progressive decrease of plasma thromboplastin activity during incubation with haemolysate or with saline was investigated.

Test for Clot-retraction Promoting Activity.-Clot retraction of samples of platelet-poor plasma, to which different concentrations of haemolysate or controls (platelets or saline) and $\mathrm{CaCl}_{2}$ were added in siliconed graduated tubes, was assayed by the method of Macfarlane (1939).

\section{Results}

Thromboplastic Activity of Haemolysate.-This is shown either in the thrombin generation or in the prothrombin consumption of a plateletpoor plasma to which haemolysate at different concentrations was added (Table I). A $0.2 \%$ concentration of haemolysate is still effective. A slight inhibitory effect of the less dilute haemolysate was observed in both tests, but chiefly on the prothrombin consumption.

Lysed red cells can be substituted for platelets in the test of Biggs and Douglas. The greatest activity is obtained by a $10 \%$ concentration of haemolysate; an excess decreases thromboplastin formation (Fig. 1). No thromboplastin is generated when haemolysate is substituted for either $\mathrm{BaSO}_{4}$-adsorbed plasma or normal serum in the test. The activity of whole erythrocytes, if they are used in the thromboplastin generation test instead of haemolysate, is very poor, depending probably only on the few red cells damaged or lysed during washing (Table II).

The activity of haemolysate is stable and does not decrease after heating at $60^{\circ} \mathrm{C}$. for $30 \mathrm{~min}$. or after storage at $37^{\circ} \mathrm{C}$. for a week or at $4^{\circ} \mathrm{C}$.

TABLE I

THROMBOPLASTIC ACTIVITY OF HAEMOLYSATE AND INHIBITORY ACTION OF HIGHEST CONCENTRATIONS

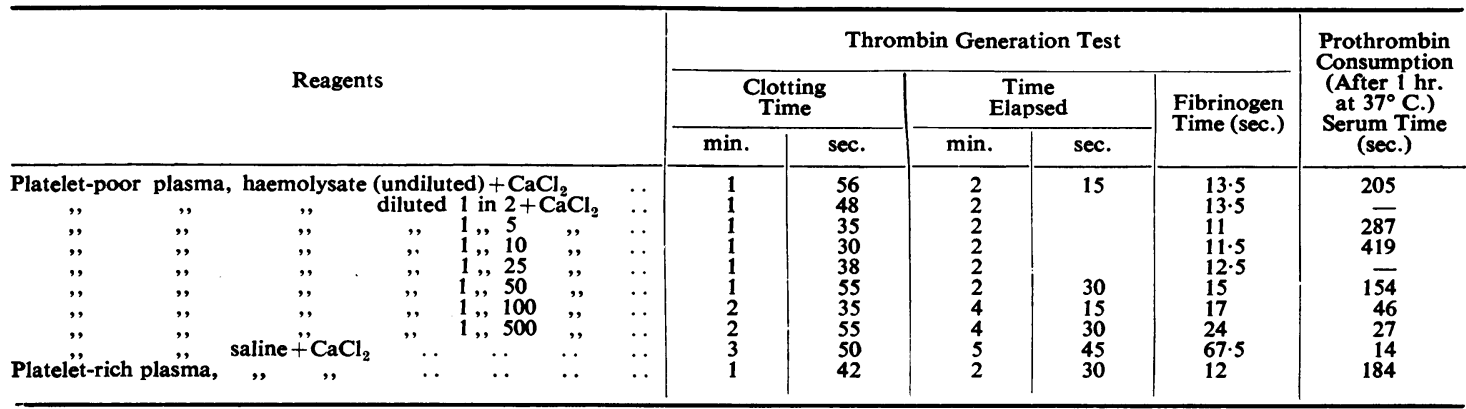




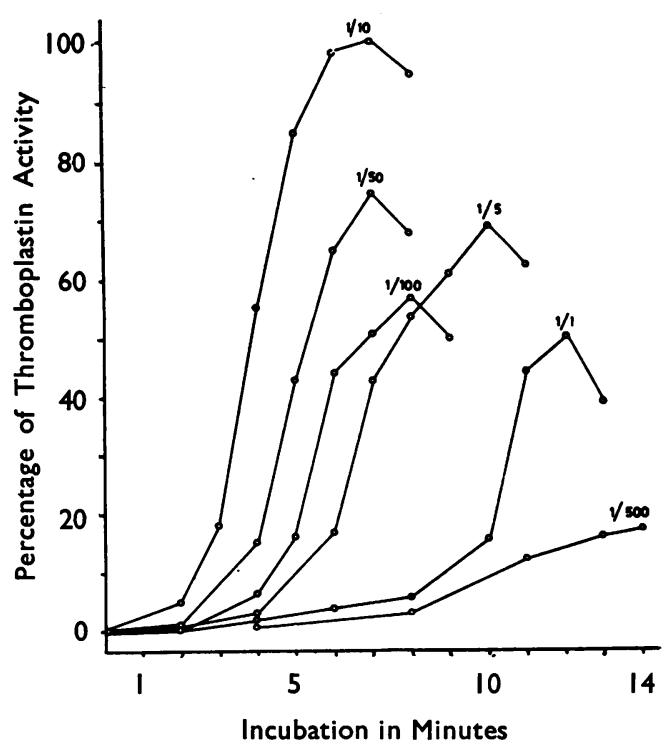

FIG. 1.-The thromboplastic effect of different dilutions of haemolysate in saline as substitutes for platelets in the thromboplastin generation test. Thromboplastin generation is inhibited with the highest concentrations of haemolysate.

for a month. It persists also after treatment with $\mathrm{BaSO}_{4}$, but disappears after extraction by lipid solvents such as acetone and chloroform.

Cases of severe haemophilia or Christmas disease may be diagnosed by the thromboplastin generation test performed with haemolysate as a substitute for platelets. Normal results can be obtained in cases of partial A.H.G. deficiency. The prothrombin utilization of blood from mild
TABLE II

SOME PROPERTIES OF ERYTHROCYTE THROMBOPLASTIC ACTIVITY STUDIED BY THROMBOPLASTIN GENERATION TEST

\begin{tabular}{|c|c|c|}
\hline \multirow[b]{2}{*}{ Reagents } & \multicolumn{2}{|c|}{ Results* } \\
\hline & $\begin{array}{l}\text { Maximal } \\
\text { Thrombo- } \\
\text { plastin } \\
\text { Generation } \\
\quad \text { (sec.) }\end{array}$ & $\begin{array}{c}\text { Incubation } \\
\text { Time } \\
\text { Elapsed } \\
\text { (min.) }\end{array}$ \\
\hline 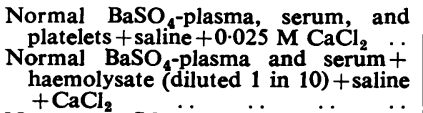 & 12 & 6 \\
\hline $\begin{array}{l}\text { Normal } \mathrm{BaSO}_{4} \text {-plasma, serum, and } \\
\text { platelets +haemolysate (diluted } 1 \text { in } \\
10)+\mathrm{CaCl}_{2} \ldots\end{array}$ & 10 & 6 \\
\hline $\begin{array}{l}\text { Normal } \mathrm{BaSO}_{4} \text { plasma and platelets } \\
\text { haemolysate (diluted } 1 \text { in } 10 \text { ) }+ \text { saline } \\
+\mathrm{CaCl}_{2}\end{array}$ & 63 & \\
\hline $\begin{array}{l}\text { Normal serum and platelets }+ \text { haemoly- } \\
\text { sate (diluted } 1 \text { in 10) }+ \text { saline }+\mathrm{CaCl}_{2}\end{array}$ & $54 \cdot 5$ & $\begin{array}{l}25 \\
26\end{array}$ \\
\hline $\begin{array}{l}\text { Normal } \mathrm{BaSO}_{4} \text {-plasma and serum }+ \\
\text { haemolysate (diluted } 1 \text { in } 10)+ \\
0.025 \mathrm{M} \mathrm{CaCl}_{2} \\
\text { In the above mixture, haemolysate } \\
\text { replaced by } \mathrm{BaSO}_{4} \text {-treated haemoly- }\end{array}$ & 10 & 6 \\
\hline $\begin{array}{l}\text { sate } \ldots \\
\text { In the same mixture, haemolysate } \\
\text { replaced by whole erythrocytes }\end{array}$ & $\begin{array}{l}10 \\
45\end{array}$ & $\begin{array}{r}6 \\
17\end{array}$ \\
\hline $\begin{array}{l}\text { Normal } \mathrm{BaSO}_{4} \text {-plasma and serum }+ \\
\text { haemolysate stored for } 7 \text { days at } \\
37^{\circ} \mathrm{C} \text {. }+\mathrm{CaCC}_{2}\end{array}$ & 9.5 & 5 \\
\hline $\begin{array}{l}\text { In the above mixture, haemolysate } \\
\text { stored for one month at } 4^{\circ} \mathrm{C} \text {. is used } \\
\text { In the above mixture, haemolysate is } \\
\text { replaced by a suspension of poowdered } \\
\text { acetone-chloroform-extracted erythro- } \\
\text { cytes } \ldots\end{array}$ & 10 & 12 \\
\hline $\begin{array}{l}\text { Normal } \mathrm{BaSO}_{4} \text {-plasma and serum }+ \\
\text { haemolysate (diluted } 1 \text { in 10) }+\mathrm{CaCl}_{2} \\
\text { In the above mixture, haemolysate } \\
\text { heat at } 60^{\circ}\end{array}$ & 10.5 & 7 \\
\hline $\begin{array}{l}\text { diluted } 1 \text { in } 10 \text { is used } \\
\text { In the same mixture, heated haemoly- }\end{array}$ & 12 & 10 \\
\hline sate (diluted 1 in 15) is used .. & 11 & 7 \\
\hline
\end{tabular}

* The shortest clotting time of substrates in each test is shown in the first column and in the second is the incubation time elapsed till the shortest clotting time was obtained.

TABLE III

USE OF HAEMOLYSATE IN TESTS FOR DETECTING SEVERE AND MILD ANTIHAEMOPHILIC GLOBULIN AND CHRISTMAS FACTOR DEFICIENCIES

\begin{tabular}{|c|c|c|c|c|c|c|c|c|c|c|c|}
\hline \multirow{5}{*}{$\begin{array}{l}\text { Case } \\
\text { No. }\end{array}$} & \multirow{5}{*}{ Diagnosis } & \multirow{3}{*}{\multicolumn{4}{|c|}{$\begin{array}{l}\text { Serum Prothrombin Activity } \\
\text { (\% Plasma Prothrombin) of } \\
0.9 \mathrm{ml} \text {. Patient's Blood }\end{array}$}} & \multicolumn{6}{|c|}{ Thromboplastin Generation Test } \\
\hline & & & & & & \multirow{2}{*}{\multicolumn{2}{|c|}{$\begin{array}{l}\text { Using Platelet } \\
\text { Suspension }\end{array}$}} & \multicolumn{4}{|c|}{ Using Haemolysate Diluted } \\
\hline & & & & & & & & \multicolumn{2}{|c|}{1 in 10} & \multicolumn{2}{|c|}{1 in 50} \\
\hline & & \multirow{2}{*}{$\begin{array}{l}+0.1 \mathrm{ml} \\
\text { Saline }\end{array}$} & \multicolumn{3}{|c|}{+0.1 ml. Haemolysate } & \multirow{2}{*}{$\begin{array}{c}\text { Maximal } \\
\text { Thrombo- } \\
\text { plastin } \\
\text { Generation } \\
\text { (sec.) }\end{array}$} & \multirow[t]{2}{*}{$\begin{array}{l}\text { Time } \\
\text { Elapsed } \\
\text { (min.) }\end{array}$} & \multirow{2}{*}{$\begin{array}{c}\text { Maximal } \\
\text { Thrombo- } \\
\text { plastin } \\
\text { Generation } \\
\quad(\text { sec.) }\end{array}$} & \multirow[t]{2}{*}{$\begin{array}{c}\text { Time } \\
\text { Elapsed } \\
\text { (min.) }\end{array}$} & \multirow{2}{*}{$\begin{array}{c}\text { Maximal } \\
\text { Thrombo- } \\
\text { plastin } \\
\text { Generation } \\
\text { (sec.) }\end{array}$} & \multirow{2}{*}{$\begin{array}{c}\text { Time } \\
\text { Elapsed } \\
\text { (min.) }\end{array}$} \\
\hline & & & 1 in 3 & 1 in 10 & 1 in 50 & & & & & & \\
\hline 1 & Haemophilia .. & 82 & - & $58 \cdot 5$ & - & $\begin{array}{c}37 \\
\text { (N. 10) }\end{array}$ & $\left(\mathrm{N}^{17} \mathrm{5}\right)$ & $\begin{array}{l}39 \\
(\mathrm{~N} .10)\end{array}$ & $\begin{array}{c}19 \\
(\mathrm{~N} .5)\end{array}$ & - & - \\
\hline 2 & , $\quad$. & 72 & - & 50 & - & - & - & $\left(N_{12)}\right.$ & 217 & 一 & - \\
\hline 3 & $\underset{(A . H . G . ~ l e v e l ~=5 \%)}{\text { Mild haemophilia }} \cdots$ & 58 & 9 & 14 & 32 & - & - & - & - & - & - \\
\hline 4 & $\begin{array}{l}\text { Mild haemophilia } \\
\text { (A.H.G. level =12\%) }\end{array}$ & $36 \cdot 5$ & 18 & 21 & 27 & $\begin{array}{l}28 \\
(\mathrm{~N} .12)\end{array}$ & $\left(\begin{array}{c}6 \\
(N .4)\end{array}\right.$ & (N. $11 \cdot 5)$ & $\begin{array}{c}15 \\
(\mathbf{N} .7)\end{array}$ & - & - \\
\hline 5 & $\begin{array}{l}\text { Mild haemophilia } \\
\text { (A.H.G. }=15 \%)\end{array}$ & 44 & - & $5 \cdot 7$ & $9 \cdot 5$ & $\begin{array}{l}18 \\
(\mathrm{~N} .12)\end{array}$ & $\begin{array}{r}6.5 \\
(N .5)\end{array}$ & $\begin{array}{l}11 \cdot 5 \\
(N .10)\end{array}$ & $\begin{array}{l}5 \\
\text { (N. 5) }\end{array}$ & $\begin{array}{c}15 \cdot 5 \\
(\mathrm{~N} .11 \cdot 5)\end{array}$ & $\stackrel{5 \cdot 5}{(\mathbf{N} .5)}$ \\
\hline 6 & Christmas disease & 55 & 25 & 30 & - & $\begin{array}{l}37 \\
\text { (N. 12) }\end{array}$ & (N.4) & (N. 11.5) & $\begin{array}{l}11 \\
(\mathrm{~N} .7)\end{array}$ & & \\
\hline
\end{tabular}


cases of haemophilia to which haemolysate was added before clotting was restored to normal, but it was only improved, though remaining abnormal, in blood from patients with severe haemophilia or Christmas disease (Table III). These results agree with the observations of Georgatsos et al. (1955) and Izarn et al. (1955) that the thrombin generation of a haemophilic plasma is increased when haemolysate is substituted for platelets in the test of Pitney and Dacie (1953) (Table IV).

TABLE IV

USE OF HAEMOLYSATE AS A SUBSTITUTE FOR PLATELETS IN THROMBIN GENERATION TEST FOR DETECTING A.H.G. DEFICIENCY

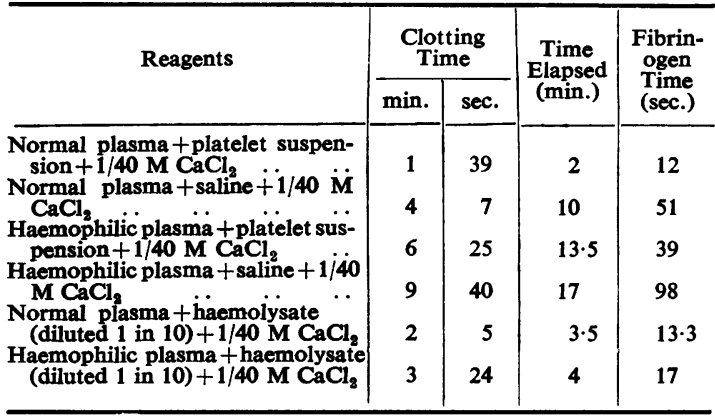

Antiheparin Activity.-Lysed erythrocytes show a marked antiheparin activity comparable to the activity of a concentrated platelet suspension, and it is directly proportional to the concentration of haemolysate and not inhibited by an excess. It is poor when 1 in 50 diluted samples are used (Fig. 2). It is stable to temperature $\left(60^{\circ}\right.$ for $30 \mathrm{~min}$.) and storage and does not decrease after treatment with $\mathrm{BaSO}_{4}$. The antiheparin effect of haemolysate is rapid and does not increase after incubation with heparinized plasma.

Effect on Other Coagulation Tests.-Haemolysate does not significantly influence the thrombin-fibrinogen reaction, but in the most concentrated samples there is a slight inhibitory action. On the contrary, platelets show a slight but constant accelerating effect (Table V).

TABLE V

EFFECT OF HAEMOLYSATE ON THROMBIN-FIBRINOGEN REACTION

\begin{tabular}{|c|c|}
\hline Solution Added & $\begin{array}{l}\text { Clotting Times in Seconds } \\
\text { (Average of Four Tests) } \\
\text { of } 0.4 \mathrm{ml} \text {. Fibrinogen }+ \\
0.1 \mathrm{ml} \text {. Thrombin } \\
\text { (2 units per ml.) }\end{array}$ \\
\hline 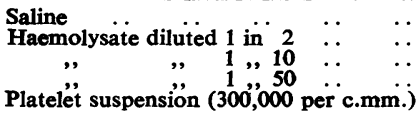 & $\begin{array}{l}16 \cdot 3 \\
19 \\
16 \cdot 5 \\
16 \cdot 5 \\
14 \cdot 5\end{array}$ \\
\hline
\end{tabular}

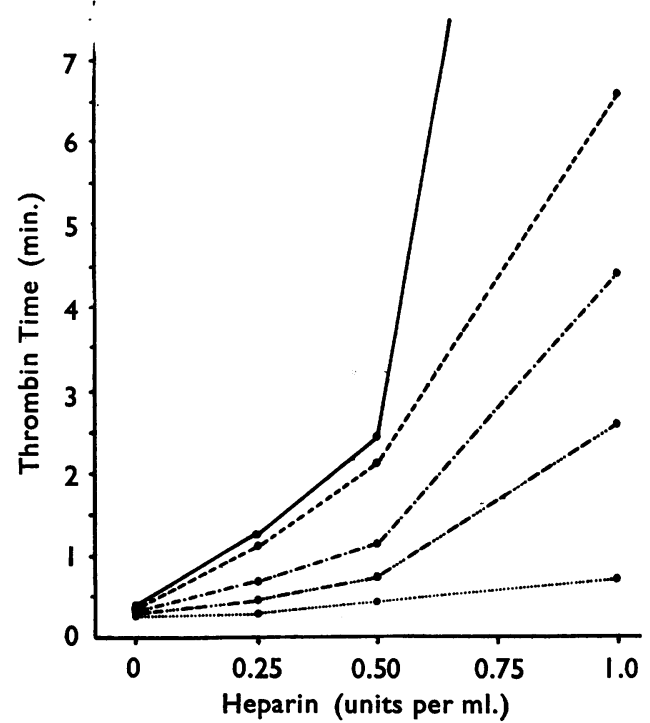

FIG. 2.-The addition of haemolysate can shorten the thrombin time of heparinized plasma. _ saline. - - - - - haemolysate diluted 1 in 50 . -........-. haemolysate diluted 1 in 10 -...-...... platelet suspension $(300,000$ per c.mm.). ..... haemolysate diluted 1 in 2 .

The clotting time of platelet-poor normal plasma to which Russell's viper venom and $\mathrm{CaCl}_{2}$ were added (" stypven " time) was markedly accelerated by the haemolysate. The accelerating activity depends on the concentration of the added haemolysate and is still present in a dilution of 1 in 1,000 . The strongest activity is shown by haemolysate diluted 1 in 10 . It does not change when using more concentrated samples (Table VI).

The highest concentrations of haemolysate inhibit the Quick time of platelet-poor normal plasma. A similar inhibiting effect of the less dilute samples of haemolysate was observed in the test for factor VII, which was not shown in the test for factor $\mathrm{V}$ activity. Very slight factor $\mathrm{V}$ activity was observed in undiluted haemolysate and it is probably due to absorbed proteins that could not be washed off the erythrocytes (Table VI).

The factor VII activity of a normal serum decreases slightly after incubation with excess haemolysate and persists unchanged if incubated with diluted samples (Table VI). No evidence of any inhibitory effect of the haemolysate on brain thromboplastin or plasma thromboplastin was shown in our experiments. No clot-retraction promoting activity was observed in the haemolysate. 
TABLE VI

INHIBITORY EFFECT OF EXCESS HAEMOLYSATE ON CLOTTING TESTS

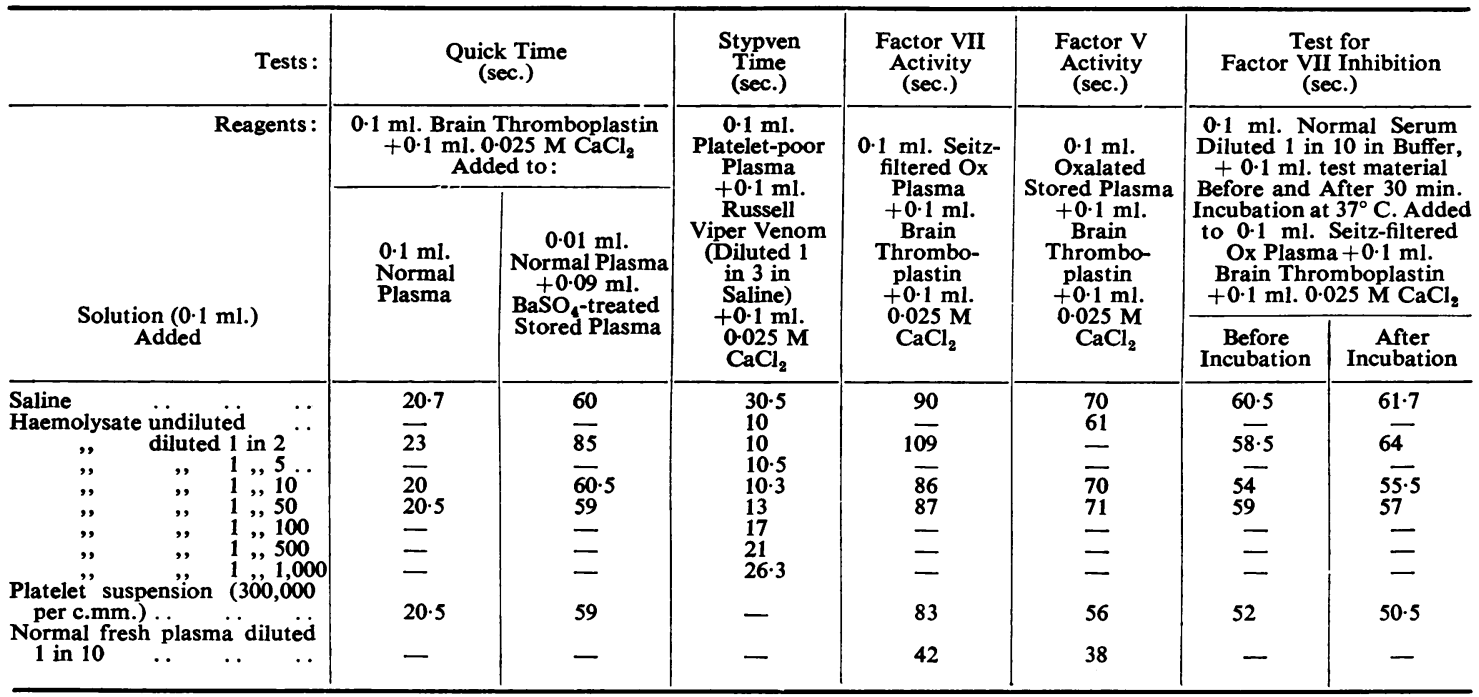

\section{Discussion}

It is known that erythrocytes contain a thromboplastic factor, probably of a lipoid nature and with a platelet-like activity. It can be substituted for platelets in the thromboplastin generation test or in the prothrombin utilization test and in assessing thrombin formation. It has been used by Bounameaux (1957b) for the assay of A.H.G. The preparation of a washed platelet suspension takes time (Wolf, 1956) and its activity deteriorates on storage due to clumping of platelets. Haemolysate, on the contrary, is fairly stable and easy to prepare. The use of a haemolysate instead of platelets might therefore be useful in coagulation tests. Our results show that in clotting tests the use of haemolysate to replace platelet suspensions is inconvenient as it makes these tests less sensitive for the detection of A.H.G. deficiencies.

It seems that the highest concentrations of lysed erythrocytes have an inhibitory effect on clotting. Similar results were obtained using concentrated platelet suspensions or lipid extracts from platelets and from brain in thromboplastin generation tests (Larrieu, Caen, and Bernard, 1955 ; Bounameaux, 1957a) and in prothrombin consumption tests (Wolf, 1956). Wolf believed that the inhibition exerted by excess lipid or platelets was due to a blockage of the reaction between thromboplastin and proconvertin (factor VII) because it does not occur in the "stypven" time. On the other hand, Bounameaux (1957a) found that excess platelets increase the rate of inactivation of plasma thromboplastin. We did not find that haemolysate had any antithromboplastin action after incubation either with brain or plasma thromboplastin. Since inhibition is exerted by concentrated haemolysate on thromboplastin and thrombin generation and on Quick time, while it does not occur in the presence of Russell's viper venom, this action is probably identical with that previously described for excess lipid and platelets. Our results support such a view. It cannot, however, be explained by this theory why inhibition takes place during plasma thromboplastin generation, for which, according to Ackroyd (1956), factor VII should not be required. Slight inhibition by the concentrated haemolysate of the thrombin-fibrinogen reaction was also observed.

We cannot explain whether inhibition from excess haemolysate might be due to a specific antithromboplastic substance, such as Tocantıns' lecithin fraction from brain (Tocantins, Carroll, and McBride, 1948), or to a different activity of the same thromboplastic factor at different concentrations. Wolf (1956) and Bounameaux (1957a) believe that gross excess of one clotting factor can cause an inhibitory effect. On the other hand, Barkhan, Newlands, and Wild (1956) have isolated two phospholipids, phosphatidylethanolamine and phosphatidyl-serine, from acetone-dried brain tissue, the former accelerating and the latter inhibiting plasma thromboplastin generation. Therefore, the possibility of the presence in the erythrocytes of various 
phospholipids with different accelerating or inhibiting activities cannot be excluded.

Erythrocytes as well as platelets can block the antithrombin activity of heparin. According to Deutsch et al. (1955) platelet antiheparin factor is different and separable from the thromboplastic factor by ultracentrifugation. The heparinneutralizing faculty of red cells behaves like the erythrocyte thromboplastic activity, but it is much less in progressive dilutions of the haemolysate and it is not inhibited by an excess. Because of the different mechanism of the two activities, there is no $\epsilon$ vidence to assume the existence of two different factors in erythrocytes.

The lipoid factor, isolated from erythrocytes by de Vries, Kettemborg, and van der Pol (1956), was claimed to be devoid of antiheparin activity, but actually it was inactive on the thromboplastin generation test also and it could only shorten the "stypven" time. Therefore, the only evidence following from de Vries' results is that the accelerating effect on "stypven" time is not always associated with thromboplastic activity and cannot be identified with it.

\section{Summary}

The activity of lysed human erythrocytes in the various stages of the clotting process was investigated. Some characteristics of erythrocyte thromboplastic activity were defined by the use of different tests. The mechanism of the inhibitory effect of concentrated haemolysate was investigated. It may be due to an inhibition of factor VII. Slight antithrombin activity was also observed. It was found that the use of haemolysate as a substitute for platelets makes clotting tests less sensitive to detect A.H.G. deficiencies.

A stable antiheparin activity was detected in erythrocytes.

\section{REFERENCES}

Ackroyd, J. F. (1956). Brit. J. Haemat., 2, 397.

Barkhan, P., Newlands, M. J., and Wild, F. (1956). Lancet, 2, 234.

Biggs, R., and Douglas, A. S. (1953). J. clin. Path., 6, 23.

Bounameaux, Y. (1957a). Acta haemat. (Basel), 17, 65.

- (1957b). Ibid., 17, 355.

Deutsch, E., Johnson, S. A., and Seegers, W. (1955). Circulat. Res., 3, 110 .

Georgatsos, J. G., Hussey, C. V., and Quick, A. J. (1955). Amer. J. Physiol., 181, 30.

Izarn, P., Hussey, C. V., and Quick, A. J. (1955). Sang, 26, 633.

Koller, F., Loeliger, A., and Duckert, F. (1951). Acta haemat. (Basel), 6, 1.

Larrieu, M. J., Caen, J., and Bernard, J. (1955). Rev. Hémat., 10, 719.

Leupold, R. (1955). Schweiz. med. Wschr., 85, 911.

Macfarlane, R. G. (1939). Lancet, 1, 1199.

Merskey, C. (1950). J. clin. Path., 3, 130.

O'Brien, J. R. (1955). Brit. J. Haemat., 1, 223.

Ottaviani, P., Dettori, A. G., and Manai, G. (1954). Arch. Sci.Med., 98, 1.

Pitney, W. R., and Dacie, J. V. (1953). J. clin. Path., 6, 9.

Quick, A. J., and Favre-Gilly, J. E. (1949). Blood, 4, 1281.

and Stefanini, M. (1948). J. Lab. clin. Med., 33, 819.

- Georgatsos, J. G., and Hussey, C. V. (1954). Amer. J. med. Sci., 228, 207.

Serafini, U. M., and Centurelli, G. (1957). Progr. méd. (Napoli), 13, 645.

Shinowara, G. Y. (1951). J. Lab. clin. Med., 38, 11.

Tocantins, L. M. (1943). Amer. J. Physiol., 139, 265.

- Carroll, R. T., and McBride, T. J. (1948). Proc. Soc. exp. Biol. (N.Y.), 68, 110.

Vries, S. I. de, Kettemborg, H. K., and Pol, E. T. van der (1956). Sangre, 1, 421.

Wolf, P. (1953). J. clin. Path., 6, 34.

(1956). Brit. J. Haemat., 2, 375. 